\title{
CULTURAL HERITAGE - A CHANCE FOR TOURISM
}

\author{
Vladimir Davidović \\ Ministry of Justice of the Republic of Serbia, \\ Belgrade, Serbia
}

\begin{abstract}
:
The first part of this text contains review of traces of Serbian (cultural heritage in the neighboring countries, and other countries as well, where it has been preserved usually as movable cultural property. Information about famous Serbs in service of other countries, who are important for Serbian history, is also mentioned. The second part contains arguments in favor of merging of cultural and tourism fields under the competence of single ministry, modeled on examples of some other countries where it gave good results.
\end{abstract}

Keywords:

cultural heritage, foreign countries, tourism, culture, Serbia, ministry

\section{INTRODUCTION}

In its long and turbulent history since the emergence of Serbian medieval state until now, significant parts of Serbian people migrated and reached places beyond the Republic of Serbia as a state, and even former Yugoslavia as the unique cultural area of Serbian people.

\section{BORDER AREAS OF SERBIAN PEOPLE - UNEXPLOITED OPPORTUNITY}

The science in the Republic of Serbia has tried to establish the traces of the farthest borders of our migrations with various successes.

In Italy, starting from Trieste, through Venice and Rome to Bari, there is a lot of it. The magnificent temple of Serbian Orthodox church dedicated to Saint Spyridon is in Trieste, and there are also numerous palaces built in that city by Serbs. In Trieste cemetery there are monumental gravestone monuments at family tombs of former powerful Serbian merchant families. Few years ago there was an exhibition and valuable printed catalog from the exhibition dedicated to Serbian traces in Trieste.

No other town in Italy was processed in similar manner. Traces of activities of numerous notable Serbs can be occasionally found in Rome. Unfortunately, there is no inventory, or description or markings of places important for Serbian history in Italy that could be attractive for tourists. 
As an example I will mention that the Queen Helen of Anjou, for which the Serbian King Uroš I had planted lilacs in the valley of river Ibar, so the bride could pass through valley of lilacs to come and sit to Serbian throne next to him, represented the branch of the line of the House of Anjou of Naples, with lot of historical data about it, but not very well known among us. The second example is not very well-known history of silver altar in the church of Saint Nicholas in Bari, above whose reliquary there is even today a silver-bound icon, gift from Serbian King Stefan Uroš III Dečanski, and there is also a donation charter of Emperor Stefan Dušan.

The icon of St. Peter and Paul, made by the end of $13^{\text {th }}$ century, was given as a gift to the Saint Peter's Cathedral Treasury in Rome (Tatić-Đurić, 1967), and the donators were Queen Helen and her sons Dragutin and Milutin.

The Cross of St. Sava is kept in the Cathedral in Piacenza.

The right hand of St. John the Baptist, which St. Sava most probably brought to Serbia and donated to the Monastery in Žiča, arrived to Serbian Patriarchate in Peć. Prior to the downfall of Serbian State, the relic was taken by Jelena, the widow of despot Lazar, the youngest son of Serbian ruler Despot Đurađ Branković. Thomas Palaiologos, the Despot in Morea, took it in 1461, running from Turks, brought it to Italy and he gave it as gift to the Pope Pius II, and the Pope donated it to the Cathedral in Siena. (Popović, 1938)

The icon with a picture of Patriarch Pajsije from the beginning of $17^{\text {th }}$ century, the unique portrait in old Serbian art (Radojčić, Ritratto del Patriarca Serba Paisi, 1955), is kept in the National Museum in Ravenna. The Hval's Codex from $1404^{5}$ is in the University Library in Bologna. (Đurić, 1957)

In the Marciana Library in Venice, there is an illustrated biography of St. Tryphon, the Protector of the town of Kotor, and one Bosnian manuscript from $15^{\text {th }}$ century.(Maksimović, 1956) within the manuscript legacy of Giuseppe Praga from Zadar, there are Serbian incunables and manuscripts originating from Dalmatia.

Fortunately, we have a special report at this gathering dedicated to traces of Serbs in Italy, by the reputable researcher Dr. Mila Mihajlović.

In Austria, the situation is a little bit better, since the places where Vuk Karadžić and Dositej Obradović used to live are known in Vienna. The first Serbian church in that city still exist, and right next to it, as an uncharted location, there is a pub where fake Serbian Count Georgije Branković was staying several years in the house arrest. There is also monument of Vuk Karadžić, and the place from where his remains were transferred to Serbia is also known. At the Vienna cemetery of Hietzing there is a big monument dedicated to Svetozar Borojević, the Austrian Feldmarschall of Serbian origin.

One of the most significant collections of Serbian medieval books and manuscripts is located in the Austrian National Library. It contains collection of 27 significant Serbian manuscripts, sold by the monks of Hilandar Monastery after the Greek uprising in 1827, who were forced to it due to famine in the Holy Mountain by that period.7 (Ivić, 1951) Kalpak of Mehmed Pasha Sokolović, who is of Serbian origin, is kept in the Art and History Museum in Vienna.

What has not been sufficiently studied, for example, are traces of plunder of Serbian cultural treasure during the Second World War. It primarily concerns museums, archives, and libraries, including a part of medieval manuscripts. The proof that such undiscovered treasure exist is the fact that after so called "democratic changes" in Serbia, a copy of film "Coronation of King Peter" magically emerged as Austria's gift. It has not been established whether it was a copy which was stolen in Belgrade during the Second World War or maybe it was a copy from the time when the film was recorded in 1903.

The University of Vienna, where numerous Serbian scientists and artists were studying, was not scientifically studied as well. It is worth to mention that there is still the Armenian Mekhitarist Monastery in Vienna, where numerous books were printed by beginning of $19^{\text {th }}$ century in Serbian language of authors such as Vuk Karadžić, Đura Daničić and Njegoš.

In Hungary there are two most important spots. Szentendre, as a small town with five Serbian churches is tourist attraction by itself, primarily thanks to Hungarian visitors, although there are all elements in it for quality presentation of our national role. This beautiful town is rarely found in maps of our tourist organizations or school excursions.

Situation in Budapest is different. In this city, which is a tourist Mecca by itself, traces of Serbs are almost completely destroyed. From former Racvaros, the whole part of town on Budim side, today there is only a 
part of building which is known it used to be Serbian. The glorious tradition of the education center is kept by Tekelianum, which is thanks to understanding of the Hungarian Government the natural center of gathering of the remains of Serbian national minority in Hungary.

Numerous Serbian villages, with still existing traces of Serbian Orthodox churches, have been destroyed in two world wars, the population was killed or displaced, and everything was inevitably forgotten. Thanks to the efforts of SANU and its Saint Andrej Committee, there is a scientific publication which is called Santandrejski zbornik, where one can find very interesting information that might help touristic presentation of Serbian traces in Hungary.

A slightly better situation is in Romania. After disintegration of Austro-Hungarian Monarchy and emergency of new states at its former territory, large part of Serbian people remained to live in Romanian Banat, and in Poljadija and in Karansebes.

The most important Serbian institutions are in Timisoara, where organized Serbian national minority is acting. There is a high school, Serbian Orthodox Bishop's Palace and magnificent church. Temples exist also in some villages of Poljadija (Ketfel-Ivanovo), while in Karansebes people were dislocated with only few exceptions (the last time it was persecution into the Baragan Plain, after the Resolution of Informbiro in 1948). Out of thirty former monasteries, only the monastery of Bazjas is active now.

Pilgrimage trips and worship of Saint Petka, whose relics rested in Belgrade as well, where part of it still exist, are also interesting. Only recently tourist trips are organized with visits to Romania and to the monastery with relics of Saint Petka in Iaşi.

It has not been scientifically studied enough, what was the destiny of large real estates of Knez Miloš who lived in Wallachia when he was persecuted, as well as of real estate's belonging to Captain Miša Anastasijević, the great Serbian benefactor, who was buried in Arad. Timisoara Committee of Matica Srpska is scientifically taking care about Serbian traces in Romania.

In Bulgaria, unfortunately, there is nothing similar. During the both world wars in the $20^{\text {th }}$ century, Bulgarians have committed serious crimes at the territory of Serbia, ruthlessly plundering cultural treasury, among the other, that has not been returned until now.

The temple in Sofia where relics of great Serbian King Milutin are located is generally known as the "church at the king", despite the fact that the temple is dedicated to the "Holy Sunday".

The fate of one of the most beautiful dual icons from $14^{\text {th }}$ century, most probably the work of some workshop in Constantinople, donated by Serbian noble family Dejanović to its endowment, monastery of Poganovo, near Caribrod, is very exciting. It represents "the miracle of monastery Lakom" on one side and on the other side the Virgin Mary with St. John the Theologian. Until 1915 it was in Poganovo, when it was taken to Sofia by Bulgarian occupiers.

It is worth to mention the collections of Serbian medieval manuscripts, especially the one in the National Library in Plovdiv.

Although, for example, it is known that Saint Sava was staying, and even died in Bulgaria, there is no any scientific body to deal with Serbian cultural heritage in Bulgaria.

Situation in Greece is different. Although Greece is very popular tourist destination, and the Holy Mountain is visited by numerous worship journeys, there are still many questions without the answers.

The Hilandar Monastery with its glory and importance has overshadowed all other issues of the presence of Serbs in Greece, and it is often neglected that the whole history of the Holy Mountain is full of Serbian traces.

The Hilandar Monastery, according to "Iviron acts", dates from the $10^{\text {th }}$ century. Then Greek monastery Hilandariu was abandoned and feeble by that time, and in Greek documents all until the second half of $12^{\text {th }}$ century (1169), is mentioned as property of Greek Monastery of Konstamonit.

Dimitrije Obolenski in his work "Six Byzantine portraits", describes founding of Hilandar as Serbian monastery, saying that in 1193 Rastko Nemanjić came to the Holy Mountain who was tonsured in the monastery of Panteleimon and took the monk name Sava. In 1198, his father joined him at the Holy Mountain and took the monk name Simeon. In the same year, both the father and the son received the imperial charter with golden seal entrusting the former Greek Monastery to them that shall "serve for staying of Serbs who choose 
the life of monk". In so far unexcelled monograph about Hilandar, academics D. Bogdanović, V. Đurić and D. Medaković mention that the Hilandar, with the status of Byzantine imperial lavra, was the best diplomatic representation of Serbia in Byzantine.

Emperor Stefan Dušan, by the time when the Holy Mountain became part of his empire, kept high respect for the Byzantine emperor, and he was giving valuable gifts to almost all monasteries at the Holy Mountain. His empire included Macedonia and Halkidiki Peninsula with the Mount of Athos, and he moved his capital to Ser. His beneficiations regarding the Hilandar are documented and well known. But it is less known that he aided other monasteries at the Holy Mountain, and especially monasteries of Dochiariou, Esphigmenou, Great Lavra, Philotheou, Vatopedi, Xenophontos, Xeropotamou and Zographou. In the time of Catalan's siege the monastery of Panteleimon was demolished, and due to the Mongolian attacks, the Kiev Russia was not able to send monks to the Mount of Athos. Due to it, Emperor Stefan Dušan gave valuable gifts to this monastery and populated it with monks from Serbia.

Grigoriou Monastery, according to data from 1489, was called Serbian monastery, although it was mentioned for the first time in 1347. The year of foundation of this monastery is not known, and it is also unknown who was the founder. It was probably some Gregory, but in was not the famous Gregory of Sinai who left from the Mount of Athos in 1330.

In the work of I.T.S. Papadopoulos: "Simonopetra - Mount of Athos" it is mentioned that the original building of Simonopetra Monastery was erected about the year 1257. Serbian Despot of Ser, Duke Jovan Uglješa received approval from the Holy Communion to erect new building "at that desolated place". Jovan Uglješa issued in 1368 charter with golden seal about it and he donated many real estates to the Monastery to support the monks and he decorated the magnificent church and residences with valuables and art objects.

In his "Travel Diary", V.G. Barski witnessed that in 1744 Simonopetra Monastery was in very bad condition. According to an archive document from 1762, quoted by him, one Serbian priest with fraternity of 35 monks intended to take over the Monastery and to take care of it. That allegedly Ser was in fact Russian saint Paisius Velichkovsky who founded the skete of Prophet Elijah.

From the work of S. Binon "Original legends about Xiropotamo and Saint Paul" it can be seen that the Monastery of Saint Paul was founded by the end of $9^{\text {th }}$ or beginning of $10^{\text {th }}$ century, as a branch of Xiropotamo. In the eighties of the $14^{\text {th }}$ century, Gerasim Branković and Arsenije Bagaš, Serbs from Kostur, repurchased the land where this monastery was build and constructed new, Serbian monastery, and with aid of Serbian and Byzantine court they provided it with lavish income and estates.

Monastery Konstamonitou was founded in $10^{\text {th }}$ century. After the fire by beginning of $15^{\text {th }}$ century, its Abbot Neophytos asked for help from Serbian landowner Radič Postupović. Postupović was the owner of the silver mine in Novo Brdo, and he funded renewal of Monastery Konstamonitou from his own funds. The Monastery was successfully developing during the $15^{\text {th }}$ century, and it was noted in scientific literature that the Mount of Athos became by that time a refuge not only of poor people but also of rich nobleman who searched for refuge from unrests of $15^{\text {th }}$ century in Balkan Peninsula.

B. R. Gotoni in his monograph "Stories and Truth: Pilgrimage to the Mount Athos - The Past and The Present", mentions that the Russian monk Isaiah visited the Holy Mountain in 1489 and saw that five monasteries were predominantly Serbian - Dochiariou, Grigoriou, Dionysinou, Saint Paul and Hilandar. Monastery Konstamonitou could have been added to this list something earlier.

Helena, wife of Byzantine Emperor Manuel Palaologos, and daughter of Prince Dragaš Dejanović, donated to the Monastery Dionysinou a lavish silver cross with the show of Crucifixion. (Mošin, Cross of Empress Helena, daughter of Prince Dragaš, 1937)

An example of nobleman generosity is also reliquary of Musić brothers, the heroes of Kosovo, donated to their endowment the Monastery of Holy Presentation in Pavlica, which is kept now in the treasury of Monastery Vatopedi at the Holy Mountain. (Grujić, 1941)

Regarding the dispute between the Monastery Vatopedi and the Greek State about the land around the lake Vistonida in Thrace in 1993, it has been discovered that this land was donated to the Monastery Vatopedi by the Charter with golden seal of John V Palaologos, and after it belonged to Serbian ruler of Ser, and he returned it to Vatopedi in 1371 as his personal donation. 
In the $16^{\text {th }}$ century, Russian Emperor Ivan IV Vasilyevich the Terrible, allowed to monks of Hilandar and Vatopedi to beg in Russia, which was by that time usual way of collecting contributions for monasteries. In 1591, Russian Emperor Feodor Ivanovich issued Charter with golden seal to Hilandar Abbot Gregory, empowering him to take care about renewal of Rusik. Although the Monastery St. Panteleimon, Rusik is an integral part of it, received aid from other Serbian grandees, its decline has not been stopped.

A special destination is the island of Corfu with the Serbian House in it, the island of death Vido, and military cemetery Zeitenlik in Thessaloniki (it is interesting that the name of cemetery is of Turkish origin, not of Greek one). There is also tourist destination for the group of monasteries Meteora, where in one of it the last known descendant of Nemanjić Dynasty rests. What is not culturally or touristic verified are traces of journey of Saint Sava to the Holy Mountain, although TV Novi Sad had recorded a documentary film about it.

There are no marked traces in Thessaloniki about the stay of Serbian Government during the exodus in 1915, and there are also no traces or markings that the town of Ser was the capital of state of Serbian Emperor Dušan.

Albania is a special case. Because of historical circumstances, presence of Serbs at the Lake Skadar and its surrounding, in a part belonging to Albania, remained unexposed in a great part. On the Montenegrin side of the Lake, remains of temples and castles that remind us of Vladimir and Kosara - whose love represented pre-Nemanjić version of Romeo and Juliet, are relatively well preserved. The miracle of cross on mountain Rumija above city of Bar became well known only after incredible decision of modern Montenegro authorities to knock down small chapel dedicated to this event on that mountain top.

On the second floor of the National Museum in Tirana there is a valuable collection of Orthodox icons where the icons of Greek origin dominate; these are beautiful Italo-Cretan and also Serbian icons. This collection, under various excuses, for decades is not available for tourist offer, as well as the remains of Orthodox churches in Durres, related to Serbs as well.

Example of Turkey is almost incredible. Although one of the biggest tourist destinations Turkey, as former empire, which included Serbia as its part for the period of little bit less than four centuries, remained from our point of view, scientifically unexposed for the most part. This indolence of Serbian science and ignoring of Turkish sources is unexplainable. The Ottoman Empire had well organized administration. There are numerous historical sources about many decisive moments of Serbian medieval and modern history for which the Serbian science even does not know that it exists, not to mention that it has been scientifically evaluated.

For example, the most luxurious illuminated Glagolitic codex, so called Hrvoje's Missal, most probably from 1405, is in the treasury of Topkapi Museum in Istanbul. (Vassilisa, 1987) The manuscript used to belong to the Library of King Matthias Corvinus, destroyed after the downfall of the Kingdom of Hungary.

The good example is the recent Agreement between the Archives of Serbia and the Turkish State Archives which is already giving outstanding results. Several thousand pages of historical documents related to our history came to Serbia until now, in electronic form. It is a sad fact that only one archivist deals with this research.

Although there is almost no any scientific studying of our cultural traces in Turkey, there is one example that cannot be avoided. It is a monograph - tourist guide about Istanbul of our prominent theologian and tourist worker Mr. Dragan Vukić. In each chapter of this valuable book there is a section "Serbs in Istanbul" which exposes historical circumstances, legal and religious position, as well as material traces of stay of Serbs in Istanbul.

These good examples cannot compensate non-existence of serious scientific program of research of Serbian historical traces in Turkey, although there are no political obstacles for it today. When it comes to Russia it is even hard to begin.

If we stick to chronology order, first we should mention Lazar the Hilandarian, of the Serb, or the Chernorizets. The sources mention all three additions to his name. It is believed that by the beginning of $15^{\text {th }}$ century he invented and built the first public clock in Kremlin that was in function for more than two centuries.

Then, there are dynastic connections from $16^{\text {th }}$ century, starting from Ana Glinskaya, maden surname Jakšić, daughter of Serbian nobleman Stefan Jakšić, well known from the Serbian epic poem "Dioba Jakšića". Her daughter was Elena Glinskaya, mother of Russian Tzar Ivan the Terrible.

Within the Kremlin walls there is a burial church of Russian Emperors, the famous Cathedral of the Archangel. There are two frescos of Saint Sava in it, or Sava the Serb or Sava Nemanjić as he is named in Russian 
Orthodoxy, a big one on the bearing north column, and smaller one at the top of the north altar column. There are also frescos of two Serbian saints, Saint Simeon and Saint Knez Lazar.

We do not know exact number of Serbian admirals, generals and other high ranked officers who participated in wars led by Russian Empire. Only those with the best achievements are remembered, and those among them who got titles of nobleman. In Russian army, from $17^{\text {th }}$ until the beginning of $20^{\text {th }}$ century, there were more than 30 highest rink officers, generals and admirals and numerous noblemen. In order to understand better the scale of participation of Serbian officers in Russian Army, and by that in history, we should consider that for example, according to some data, in the famous battle of Borodino, 37 generals lead the Russian army, among them dozens of Serbian origins.

Therefore, aware that I will be unjust to many worthy and important people, I will mention only those most significant. First of all it is Mihajlo Andrejević Miloradović, Russian Feldmarschall- lieutenant (it was witnessed by Sava Tekelija in his autobiography, and his predecessor Petar Popović Tekelija was also General-enchef of Russian army), the Governor of Sankt Petersburg, who was killed by the Decembrists in 1825.

Matija Zmajević lived one century before, he was the first foreign admiral in Russian Navy and he was buried in Moscow in 1735. It is worth to mention Admiral Marko Vojnović, the founder of the Black Sea Fleet and Đorđe Arsenijević Emanuel, Russian general born in Vršac who commanded with Russian Army which occupied Paris after the defeat of Napoleon in 1814. By beginning of $20^{\text {th }}$ century, Dejan J. Subotić, General was Commander of the town and Port Artur at the Far East.

Without the grandiose novel "Seobe" (Migrations) of Miloš Crnjanski, we would not know anything about the migration of Serbs to Russia (now Ukraine), at the time of Empress Katarina, the wife and successor to the throne of Peter the Great. Crnjanski used for his novel diaries of Simeon and Aleksandar Piščević, the first one was the General, and his son was Colonel in Russian Army. Nova Serbija, led to migration by General Jovan Horvat, was founded in 1752, and Slavijano Serbija, led to migration by Generals Jovan Šević and Rajko Preradović (Rodion De-Preradovich) was founded in 1753. Both military and administrative units were abolished in 1764.

Serbian Hussar Regiment, composed from Serbs from the Military Frontier, was founded in 1723, and ceased to exist in 1783. Its first Commander was Jovan Albanez, originating from Podgorica. Sava Lukić Vladislavić, the secret advisor to the Peter the Great, was probably the most powerful Serb of all times, after the Emperor Dušan. His life and work deserve a special scientific conference. Jovan Dučić wrote extraordinary monograph about his life. He had founded the town of Troickosavsk, now Kjahta in the Republic of Buryatia. He rendered great services to Peter the Great and he was richly rewarded for it. By the decision of the Centre of National Glory of Russia he was placed in the Russian Pantheon, and monument dedicated to him was raised in the small town of Shlisselburg, near the Sankt Petersburg, at his estate that he received as reward from the Peter the Great. In June 2018, his monument was also raised in Kjahta, former Troickosavsk. He was buried in the Church of Annunciation of the Nevsky Monastery in Sankt Peterbur, with several other famous Serbs. Great Russian General Suvorov was buried next to him, one century after.

Aleksandar Knjažević is also worth mentioning, and he was Russian Ministry of Finance and Senator. As well as Atanasije Stojković, Rector of the University of Kharkov, and the inventor Ognjeslav Kostović Stepanović who constructed his original version of dirigible. Acting of such big number of dignitaries in Russia - Serbs or of Serbian origin deserves comprehensive, detail scientific studying.

In 1874, Metochion of Serbian Orthodox Church was opened in Moscow, and Russian authorities gave to Metropolitan Mihajlo one Orthodox Church and house in part of Moscow called Seljanka. It was the only official Serbian representative office, until opening of Serbian General Consulate in Moscow in 1897. That Consulate was in the street Mala Jakimanska. Before it, the only Serbian mission was in Sankt Petersburg. It should be mentioned that within the Russian Orthodox Church the Metropolitan was Serb Jefrem Janković Tetovac, and Jovan Šangajski born in Russia as Mihailo Maksimović, whose father Boris was Serb, was not only the Bishop of Russian Orthodox Church, but he also became the saint.

Stefan Verković as Commissioner of Serbian Government travelled in Old Serbia, where he was sent by Ilija Garašanin. His collection of manuscripts and other antiquities of total of 35 pieces, was sold to the Public Library in Petrograd after long negotiations in 1891. (Vajs, 1948) 
In Russian libraries large number of Serbian medieval manuscripts is kept. (Nemirovski, 1967) One part of it belongs to legacies of Russian travelers-explorers from $19^{\text {th }}$ century, V. Grigorovich for example, who travelled to the Mount of Athos and Turkey in 1844-46. That collection was donated to Rumjancovski Museum, University of Kazan and to Kazan Theological Academy. The largest part of collection, 54 manuscripts, was donated to Novorossiysk University in Odessa. (Stanojević, 1937) More than 1500 manuscripts of Slav origin was collected from 1845-1864 by V. Undolski. That collection, as well as the previous, was purchased for the Rumjancovski Museum in Moscow. Part of collection of Russian Consul in Sarajevo, A. Hilferding, was donated to the Public Library in Moscow when he was still alive. The other part was bought by merchant Hludov and donated it to the Transfiguration Monastery near Moscow.

In the catalog of printed books of the Church Museum in Lvov from 1908 it can be seen that the Museum had possessed the Book of Psalms with the Book of Hours printed in Venice for Božidar Vuković in 1519, Posni Triod from the half of $16^{\text {th }}$ century, Cvetni Triod of Camillo Zanetti printer in Skadar in 1563, Praznični Oktoih printed in Venice in 1537, Služavnik printed in Venice in 1570, and Molitvenik printed in Venice in 1547. (Svjencički, 1908) From the book of $18^{\text {th }}$ century, the Museum possessed "The Monks Rules" of Karlovac Metropolitan Vićentije, printed in Vienna in 1774, and a very rare book "New Slav Rules" cut in Sremski Karlovci in 1776 by Zaharije Orfelin.

The following relevant examples serve as a proof that this situation was not specific to the neighbouring countries nor to the countries where Serbian people migrated to or were persecuted to:

In Spain, in the treasury of the Cathedral in Cuenca, there is a richly decorated reliquary of Despot Toma Preljubović. In England, in the British Museum, Tetraevangelion of Jovan Metropolitan of Ser from the middle of $14^{\text {th }}$ century is kept. (Harisijadis, 1964) In Ireland, in Dublin, in the library of Chester Beatty Foundation, there is the Nikolje Gospel from $14^{\text {th }}$ century, that used to belong to Nikolje Monastery in the Ovčar-Kablar gorge, and it was scientifically processed by Đura Daničić. (Mošin, 1968)In Germany, in the Berlin Library, there is so called Romanov Tipik from $14^{\text {th }}$ century, published by theologian and Byzantologist Laza Mirković. (Marković, 1956)

The Serbian (Munich) Psalter had an unusual destiny. It is luxuriously illuminated Serbian manuscript from the second half of $14^{\text {th }}$ century that was most probably made for Serbian Empress Jelena, wife of Emperor Dušan. (Radojčić, 1950) This manuscript, with about 150 miniatures, belonged to Nemanjić castle. Later on, it came to library of Despot Đurađ Branković, and after the downfall of medieval Serbia, the Psalter was transferred to Srem, where it became property of Despot Vuk Grgurović, tha last of Branković bloodlines. In 1485, the manuscript came to the Monastery Pribina Glava in Srem. Some Bavarian officer took it from there as the prize of war, during the so called "Vienna War" and donated it to the library of Bavarian Monastery Gotescel. After secularization in Bavaria, by beginning of $19^{\text {th }}$ century, the Psalter became the property of newly founded Bavarian National Library in Munich, where it is kept today.

Property of Serbian National Library was plundered in the First World War. The original Nemanja's Charter of Founding of Hilandar Monastery disappeared then. Dozen manuscripts were found later and repurchased from private owners in Germany which indicates that other manuscripts that were evacuated from Belgrade might still be found. (Medaković, 1970) ${ }^{1}$

In France, in the National Library in Paris, there is the Life of St. Simeon written by Stefan the FirstCrowned within the Collection of Sermons, as well as manuscript of the Life of Saints, originating from second decade of $14^{\text {th }}$ century, as well as several other Serbian manuscripts among it so called Paris Manuscript, the description of transfer of Saint Luke's relics to Smederevo in 1453. (Medaković, 1952)

In Denmark, in the Royal Library in Copenhagen, there is the Fund of old printed books and manuscripts from our country, indicated by Danish Slavist Gunnar Svane. (Gunnar, 1968)

In the Czech Republic, in Prague, in the Czech Museum, there is collection of 30 Serbian manuscripts, where it came as legacy of Pavel Jozef̌́afarik, who received it as gift from his Serbian friends Samuil Maširević, Platon Atanacković and Bishop Stanković. (Stanojević, 1937) 
In Egypt, in the Monastery of St, Katarina in Sinai Desert, recent research confirmed existence of medieval manuscripts in this ancient Orthodox monastery.

\section{ORGANIZATIONAL MODEL OF STATE AUTHORITIES COMPETENT FOR CULTURE AND TOURISM}

In this part of my text I will draw your attention to organizational model of state authorities dealing with culture and tourism, which exists in several countries, among it I am going to mention the United Kingdom, Greece, Turkey, Russia, Denmark, etc.

In those countries, the single ministry has competence in issues of culture and tourism. Although, at the first glance this connection is not organic, the arguments for such organizational model of the state institution might serve both as an example and as a theme for thinking in our country as well.

Out of numerous arguments, for this occasion I will draw your attention to three of it:

a) Reconstruction of cultural monuments, i.e., immovable cultural property is an expensive activity. In planning and distribution of the state funds, and establishing of priorities and deciding on investments, one of criteria is existence of organized programs for bringing of tourists (foreign tourist groups, school excursions and organized tours, and individual tourist visits). In that way, the existing protection of cultural goods is improved, with its touristic, i.e. economic valorization at the same time, and not only protection and material status of cultural goods in the narrow sense is improved, but also its cultural and spiritual mission is supported and extended in that manner.

b) State funding of cultural events - festivals, anniversaries, celebrations, beside the support to its basic cultural mission, contributes to affirmation of the activity itself, and also of communities where it is organized. One of criteria for allocation of budgetary funds is the existence of defined tourist programs for bringing of tourists to such events. In our conditions, the most famous event became recently festival Exit in Novi Sad. But, we should not forget events like FEST, BITEF, BEMUS, Guča Trumpet Festival and similar. This also applies to sporting events. Such programs should be reviewed in the light of increase of hotel capacities in the Republic of Serbia lately.

c) Proper cataloging of cultural goods must be compulsory condition for touristic presentation as well. Modern devices of electronic technologies and communications facilitate proper cataloging both of movable and immovable cultural property. Quality digital photographs and video clips, with appropriate scientific and professional descriptions of such cultural goods, might at the same time represent the most quality professional base for making of all forms of its touristic product.

Use of quality catalog documentation could achieve several objectives: adequate documenting and review of immovable cultural property, starting from archeological sites, fortresses and monasteries, to presentation of movable cultural goods, i.e. attractive museum collections. Our museums are full of world-significant artefacts, from pre-historical archeological sites, through medieval, ethnological heritage, to modern history. Therefore, investing in legally compulsory cataloging, or its revision and producing of adequate photographs and video recordings, with modern descriptions, enriched with new scientific knowledge, would significantly reduce costs of propaganda material that could be used for various educational and tourism purposes.

\section{CONCLUSION}

I - Whenever Serbian people suffered, our cultural heritage also suffered. Almost nothing has been done to make this heritage an integral part of our national awareness. And that could be done at the level of primary and secondary education which, regretfully, most often stay insensitive to this issue.

Part of Serbian cultural treasury located abroad, may be returned and joined to the unity from which it was taken mostly by use of force. The return assumes measures that would bring those antiquities to the fund of Serbian cultural heritage. Those valuables should be first registered, and then scientifically described and brought again to our science and national awareness.

Therefore, it is necessary to make scientific catalog of Serbian artistic antiquities abroad. Such catalog would enable to have a better look of the scope of enormous damage suffered by Serbian people through 
centuries. In that way, consequences of calamities that were for centuries scattering Serbian spiritual heritage around would be reduced at least to some degree. It would be the most memorable testimony about the high level of Serbian medieval culture and top proof about in destructible power of Serbs, even in the most unfavorable historical conditions, to confirm themselves as historical people and to testimony about its permanent and inseparable in belonging to cultural tradition of Europe.

II - Without considering all aspects of organization of state authorities and without pretensions about such important state matters, it is my opinion that this argumentation, taking into account the experience of other countries, may serve as example how an increased attention in organizational matters contributes to avoid various bureaucratic (obstacles, associating and rationalization of existing resources, with purpose of better presentation of cultural goods to those to whom it is intended.

I have to mention with regret, that our diplomatic and consular offices, about 100 of it in the world, ceased long time ago to follow up destiny of artefacts important to us that occasionally appear at the world market of antiquities and artwork.

\section{REFERENCES}

Đurić, V. (1957). Minijature Hvalovog rukopisa. Istorijski glasnik, 1-2, 39-52.

Grujić, M. (1941). Relikvijar braće Musića. Umetnički pregled, 3, 78-81.

Gunar, S. (1968). Stare štampane knjige i rukopisi iz jugoslovenskih zemalja u kopenhaškoj kraljevskoj biblioteci. Zbornik za filologiju i lingvistiku, 271-277.

Harisijadis, M. (1964). Le miniatures du teraevangile du MetropoliteJakov de Serbes. Acta du XII Congres International. Beograd.

Ivić, A. (1951). Tri priloga za proučavanje srpske književnosti. Beograd: Srpska akademija nauka.

Maksimović, J. (1956). Rukopis sa minijaturama života i čuda Sv. Tripuna u Marcijani i njegova kotorska kopija. Zbornik Filozofskog fakulteta, IV/1.

Marković, L. (1956). Romanov Tipik. Zbornik društvenih nauka, 47-59.

Medaković, , D. (1970). Vraćanje srpskih srednjovekovnih rukopisa iz Nemačke. Bibliotekar, 4, 309-311.

Medaković, D. (1952). Naše retke štampane knjige u pariskoj nacionalnoj biblioteci. Književne novine, 59, 12.

Mošin, V. (1937). Krst carice Jelene, kćeri kneza Dragaša. Umetnički pregled, III, 136-137.

Mošin, V. (1968). Rukopisi bivše Beogradske Narodne biblioteke u Dablinu i u Zagrebu. Bibliotekar, 5, 349-358.

Nemirovski, E. L. (1967). Jugoslovenske ćirilske inkunabule u bibliotekama Sovjetskog saveza. Bibliotekar, 5-6, 265-271.

Popović, P. (1938). O srpskom natpisu u Sijeni. Prilozi za književnost, jezik, istoriju i folklor, 286(2), 214-220.

Radojčić, S. (1950). Old Serbian Miniatures. Beograd.

Radojčić, S. (1955). Ritratto del Patriarca Serba Paisi. Ravenna, 31-37.

Stanojević, S. (1937). Istorija srpskog naroda u srednjem veku 1: Izvori i istoriografija. Beograd: Srpska kraljevska akademija.

Svjencicki, I. (1908). Katalog knjiga Cerkovno-slovenskoi pečati. Žovkva.

Tatić-Đurić, M. (1967). Ikona apostola Petra i Pavla u Vatikanu. Beograd: Zoograf.

Vajs, I. (1948). Najstariji hrvtsko-glagolski Misal. Zagreb : Djela JA.

Vassilisa, É. (1987). L'art Thessalonique et au'paqu Balkaniques. Les Courants spirituelle au XIV siecle, 57-65. 